\title{
SHEA/CDC/AHA Training Program Scholarships
}

As this issue goes to press, the September 17-20, 1992, offering of the SHEA/Centers for Disease Control (CDC) /American Hospital Association (AHA) Hospital Epidemiology Training course is underway in Atlanta, Georgia. Among the attenders are five recipients of Merck scholarships, which provided $\$ 1,000$ each to help cover the transportation, lodging, and tuition expenses of the awardees. The winners were selected by the Educational Activities Committee from a field of 28 infectious disease fellows who had applied for the highly competitive scholarships.

The scholarship winners (and sponsors and institutions) were: Dr. Manuel Arbo (Dr. David Snydman, New England Medical
Center Hospitals); Dr. Stephen R. Barone (Dr. Leonard R. Krilov, North Shore University Hospital); Dr. Robert A. Duncan (Dr. Donald E. Craven, Boston City Hospital); Dr. Kathryn Kirkland (Dr. David T. Durack, Duke University Medical Center); and Dr. Kathy Kulak (Dr. Dennis Maki, University of Wisconsin Medical School). Congratulations!

\section{International Latex Conference: Sensitivity to Latex Medical Devices}

The Food and Drug Administration (FDA) and the Centers for Disease Control will sponsor "International Latex Conference: Sensitivity to Latex Medical Devices." This conference will provide an opportunity for the medical community, scientists, industry, and regulatory agencies to present data and exchange information about the issues of hypersensitivity reactions to latex medical devices. The program will include invited speakers, contributed oral and poster presentations, and a panel discussion. Topics to be addressed will include latex chemistry, clinical studies, protein quantification and identification, epidemiology of latex hypersensitivity, diagnostic testing methods, prevention strategies, and approaches of manufacturers and producers.

The conference will be held
November 5-7, 1992, in Baltimore, Maryland. For more information, contact FDA International Latex Conference, c/o Crosspaths Management Systems, Inc., Two Wisconsin Circle, Suite 660, Chevy Chase, MD 20815. Telephone (800) 5CPATHS.

Brief items of interest for the SHEA N ews or N ewsletter may be sent to Robert A. W einstein, M D, SHEA, N ewsletter Editor, Division of Infectious D iseases, M ichael Reese H ospital, Lake Shore D rive at 31st St., Chicago, IL 60616; FAX (312) 7913577. Copy should be typed, doublespaced, and should not exceed five pages. 